\title{
The Delinquency of Other Nationality Representatives in the Czech Republic
}

\author{
Simona Musilová*
}

Department of Developmental Psychology, Institute of Psychology, Kazimierz Wielki University in Bydgoszcz, Poland

\begin{abstract}
The delinquency of social minorities is frequently discussed, including the social minorities' victimization. The potential crime causes and the consequences for both the minority and majority provoke numerous researchers in various science fields. On the other hand, the amount of data on crimes committed by social minorities is limited due to the desire to avoid discrimination and support social inclusion into the majority society. A specific position is held by foreigners with permanent residence; however, without a citizenship. This article analyses the situation in the Czech Republic, Slovakia, Poland, Hungary, and Ukraine in terms of the general perception of delinquency, the perceived benefits and drawbacks of co-existence with a different nationality. It is important to analyse this topic because there are multiple problems in the social exclusion of other nationality representatives. These problems do not have visible solutions. Some of these problems are caused by locally increased crime rates of minorities coupled with grater rates of victimization.
\end{abstract}

Keywords: Crime, delinquency, foreigner, majority, minority, nationality, norms , social deviation, victim, victimization

\section{THE INDICATION OF NATIONAL MINORITIES' PROBLEM AS A WAY OF HELPING THEM}

Minorities and the associated delinquency permanently represent a very current and sensitive topic. Both social minorities and foreigners living permanently on a given state's territory usually differ in their customs, experiences, perception, knowledge, priorities, values, and their historic evolution in terms of ontogenesis and phylogeny. That is one the most frequent reasons why coexistence with a majority society may be problematic. Lifestyle differences lead to reciprocal misunderstandings between both majority and minority citizens. Disproportional solutions or consequences of misunderstood differences lead to illegal activities, crimes. Unfortunately, the life of foreigners and national minorities is associated in the whole world with a greater crime and victimization rates. The assumption of (Flowers, 1990) stating that minority groups must be perceived in the association with the historically poor treatment of minorities, which results in today's delinquency and victimization, cannot be applied at least to the Central European society, and it is not comprehensive enough either. Every minority's historical contexts are significant; nevertheless, they cannot be used to excuse the events under the current conditions neither from the minority's perspective nor against the minority.

Even in these days, the majority of society still perceives the issue of minorities in a black-and-white manner. The same applies to the inclusion and exclusion of minorities. Foreigners are seen as aggressors who commit crimes in a

*Address correspondence to this author at the Department of Developmental Psychology, Institute of Psychology, Kazimierz Wielki University in Bydgoszcz, Poland; E-mail: si.musilova@gmail.com particular country or as discriminated victims who cannot defend themselves. It looks like if nothing existed in between. Discrimination and social exclusion have become frequent terms primarily in politics. That shifts their meaning because their use often does not lead to any help or problem solution. Quite the opposite since other goals are to be achieved.

The detection of problematic issues in the lives of foreigners and national minority members is critical primarily for the setting of effective primary and secondary prevention. The pubic opinion of different people may be sometimes extreme or even xenophobic - it features no tangible foundation due to the lack of information on differences. That is the reason of why all the people should obtain integrated information of their subjects of interest, not hiding any details. Unfortunately, the amount of publically available information is limited. The delinquency and victimization of minority groups must be perceived through their complexity together with all of its factors and all biological, psychological, social, political, cultural, and economic aspects. The intention is to analyse the situation in the Central European region that typically features its local concentration of various minorities and various delinquency manifestations - resultantly, no global conclusions can be made.

\section{Minority Members versus Foreigners}

It is necessary to distinguish between a minority member and a foreigner living in a given country (this includes both long-term and short-term stays). Then, one can identify the positive and negative features of co-existence and different nationalities. Comprehensive approach is always necessary. The perception of all the complex aspects of life of a 
different minority may assist in the understanding of delinquency origins or, on the other hand, delinquency solutions.

The law distinguishes two terms: Minority and foreigners living on the majority's territory. Consequently, national minority members are found state citizens with all of the rights and obligations featured by the majority. The law also states that any minority membership must not harm anybody else who is not a member of such a minority (Budilová \& Hirt, 2005). It means that it is allowed to do everything associated with the minority's tradition, anything what is not in conflict with the national and European law. Unlike the West European countries, the countries of the Central and East Europe see minority membership as a subjective perception of own nationality.

Contrary to that, foreigners without their host country citizenship have limited rights and obligations because they hold their original country citizenship. They can exercise their rights and fulfil their obligations in their country of origin. Foreigners migrate due to their short-term or longterm stays in a specific country. They usually associate with their national minority, which already exists in their host country. That is the reason why foreigners are sometimes associated with national minorities - not from the legal perspective, but in terms of public opinion. Greater numbers of foreigners are identified near national borders where foreigners from the neighbouring countries often live for various reasons. The understanding the difference between these two terms is critical for a discussion on other nationalities within a state, especially in the case of delinquency.

\section{Delinquency as a Social and Psychological Phenomenon}

The understanding the meaning of delinquency is important for the subsequent evaluation of the criminal behaviour of minorities and foreigners. It is true that the discussed social deviation, social norms, and the system of punishments may not match another nationality's social expectations due to their different understanding of norms and priorities. Then, delinquency from the majority's perspective may not mean the same as delinquency seen by a specific minority. However, the criminal law is approved by all the Central-East European countries, which are mentioned hereto. It is based on the society's long-term evolution, its laws, needs, and solved problems. The area of social norms associated with delinquency should become the subject of full adaptation of every minority.

Delinquency is seen as a social-pathological problem of every human society. The forms of delinquency change with time and together with society evolution. The view of delinquency is twofold (Moulisová \& Zoubková, 2004). First, the juridical concept identifies delinquency as a very specific criminal law term. Such a delinquency concept represents a set of crimes judged according to the valid law. The other delinquency concept, marked as sociological, is wider than the criminal law specification, and it is basically independent of it. The sociological concept is based on highlighted social deviation. Deviation from social norms disturbs both formal and informal expectations (of what human expressions should be in a particular society). System of sanctions depends on the social norm character and the importance of matching or violating it (Munková, 2004). It even includes those socially-pathological phenomena, which the criminal law does not regulate. Despite that, these socially-pathological phenomena as very closely associated with delinquency. They often turn into or accompany the crime itself; for example, psychoactive substance overdose, alcoholism, prostitution, and home violence (Kuchta \& Válková, 2005). In any case, there is a significant difference between registered delinquency and latent one, even if this is difficult to judge, distinguish, and prove. It means that the crime statistics may reflect the actual situation only partially. Generally, it is possible to state that female delinquency is more often found latent, especially due to the different ways of committed offences. This means that the crime statistics may reflect the actual situation only partially.

Delinquency is usually caused by aggression, but not always. From the evolution perspective, the universal and most broadly perceived meaning of aggression is associated with aggressive act, which is the fundamental tool used to satisfy human needs (Bandura, 1977; Baumaister \& Bushman, 2004). The majority of psychologists agree that aggressive behaviour is such a type of behaviour whose intention is to cause harm to a person or item (Dollard et al., 1939; Bandura, 1977; Anderson \& Bushman, 2002). Simultaneously, aggression is divided according to its expression, for example, into direct and indirect, verbal, physical, active, and passive aggression (ignorance with the intention to cause harm), including emotional, frustration, and instrumental aggression (Martínek, 2009). Aggression does not necessarily mean hostility or anger. It rather includes internal feelings and experiences sublimating in various ways - not only through manifested aggressiveness (Ramírez \& Andreu, 2006).

A discussion on crimes must necessarily include victims. The American National Centre for Victims of Crime defines victimization trauma as follows:

"The trauma of victimization is a direct reaction to the aftermath of crime. Crime victims suffer a tremendous amount of physical and psychological trauma. The primary injuries victims suffer can be grouped into three distinct categories: physical, financial and emotional. When victims do not receive the appropriate support and intervention in the aftermath of the crime, they suffer "secondary" injuries." (available from:www.victimsofcrime.org)

Bard, (1986) describes victims' response to committed crime as a "crisis response". The victim will respond differently, based on the experienced personal violence level and the equilibrium state at the moment of victimization. Victims of non-violent crimes like theft may experience less of personal violence than outrage victims; however, it is not a necessary condition. From the victim's perspective, murder is the ultimate violence, and those who survived or experienced personal violence remain. Every person features his own "normal" 
equilibrium state. This normal state is affected by everyday stressors, like sickness, moving, employment changes, or family problems. If some of those changes come up, the equilibrium will change; however, it should eventually return to its normal state. When people experience the common stressors and then they are victimized, they become more to more extreme crisis responses. There are the common basic responses, which the victim will demonstrate immediately after the crime for a few hours or days. Responses to criminal victimization often include; however, they are not limited in this way: shock, deadness, denial, mistrust, anger, and eventually recovery."

\section{THE TENDENCY OF NATIONAL MINORITY MEMBERS TO BECOME A CRIME OFFENDER OR VICTIM - POTENTIAL CAUSES AND CONSEQUENCES}

The issue of victims and perpetrators will be discussed. Except them, crime spectators seem to be influenced strongly too. Mostly researches do not take into an account consequences of to become a witness. (Matoušková, 2013).

\section{Psychology of Victims}

A victim whose is a member of a national minority or a foreigner living abroad faces a very complicated situation. Besides primary victimization, there are other complications concerning the special conditions associated with foreigners.

The victimization causes are evaluated according to behavioural, personal, and social provoking factors, which may partially impact crime execution in some of its forms. For example, insufficient protection of one's own property, walking at dangerous locations without any escort, proceeding with risky groups, almost illegal behaviour or illegal behaviour - it generally applies that frequent exposure to violence is associated with greater crime rates and victimization because the empirical research results indicate that the observation of violence and aggression could be a critical predictor of aggressive behaviour in the case of a given person (Sobotková et al., 2012; Bacchini et al. 2014). Locally and socially conditioned greater crime rates are supplemented by greater victimization rates. In addition, the potential victim's appearance may also be critical because the offender usually selects a victim that looks weaker than the offender himself. In any case, there are numerous unpredictable factors preventing any possibility to influence them in any way.

It is necessary to distinguish between direct and indirect victims and also between primary and secondary victimization. Direct victim means a hurt person. However, indirect victim means a person affected or traumatized by hurting the direct victim. It could be, for example, family members or crime witnesses. Primary victimization means immediate traumatic crime experience associated with one's own harm processing. Both primary and secondary victimization may concern both direct and indirect victims.

Although there are numerous victim typologies divided according to crime types, the crisis situation processing style differs with every victim, mostly depending on personality characteristics, support level provided by the surrounding environment, stress handling style, level of harm or injury, and its impacts on common life, society's approach to such a crime and to the victims of such a crime in general, including, on the other hand, the offender arrest or at least restraining his free movement near the victim. Consequently, a typical victim with a typical response to trauma does not exist.

The terms latent victims, genuine and non-genuine victims, and highly vulnerable victims are often discussed. The latent victim is associated with latent delinquency, which still continues due to the fear to report the offender. This is often cause by numerous factors - fear of the offender's fierce revenge, financial dependence on the defender, amnesia of one's traumatic experience, fear of public embarrassment or humiliation. The non-genuine victim is not a real victim. However, he feels to be a victim because he finds himself at a wrong place at a wrong time this does not have to be associated with any crime. Unlike the genuine victim, the fabricated victimization strives to reach a completely different goal. It may include financial support or other benefits - being, more or less, fully aware of the truth. The new European legal system brings the term of highly vulnerable victim, which includes the child, person with a mental, physical, or sensual handicap preventing full inclusion, human trafficking victim, violent crime or sexual assault victims when the secondary victimization danger becomes obvious, especially in terms of age, gender, ethnicity, nationality, sexual orientation, religion, medical condition, mental maturity, ability to express one's own experiences, life situation, and one's relationship to a potential aggressor or his dependence on such an aggressor (Čírtková, 2004).

From this perspective, a victim who is a national minority member or foreigner falls into the group of highly vulnerable victims and becomes entitled to free professional counselling available in the EU countries (The White Circle of Safety in the Czech Republic is a generally focused institution. There are also numerous specialized organizations focused on domestic violence in the Czech Republic, Slovakia, and Poland).

\section{The Offender's Psychology}

There are still numerous hidden factors, and science is generally unable to explain anti-social or asocial human behaviour. Avoiding provoking factors that lead to becoming offender should be more effective than solving real cases through the application of some form of punishment. Unfortunately, even the current knowledge available in various science fields only partially prevents delinquency. The society must continuously follow invalid theory based on which the offender's motivation to avoid punishment should be greater than his motivation to commit a crime. On the other hand, punishing and one's return to the society do not seem to be clearly effective from the perspective of recidivism.

If an offender is perceived as aggressor, it is necessary to consider, first of all, his age, state of mind, and the case of self-defence or extreme distress. Psychology and law evaluate motivation, causes, and consequences differently. 
Then, two psychological approaches may be distinguished: procedural (dynamic) approach and structural (typological) approach.

The dynamic procedural concept is based on the analysis and explanation of the offender's mental processing experienced before, during, and after the crime. His mental readiness to commit a crime becomes the main problem. (Č́rtková 2004) mentions the minor differences among offender personalities: tendency to saturate one's needs immediately and urgently. This indicates the lack of discretion. There is also tendency to explain the moral and legal standards in a subjective way and make them relative (egocentrism); motivation process changed or handicapped through various forms, for example, skipping various decision-making process phases (impulsiveness), nonfunctioning internal barriers (defects of character and social intelligence), and neutralization of the consequences of one's behaviour manifested as underestimation or denial of the victim's harm.

Based on the type of perspective, there are numerous offender typologies. In general, the offender's attributes are so heterogeneous and diverse that they cannot be classified. In addition, every classification easily generates undesirable stereotypes and labelling.

The special position in criminal science belongs to racemotivated crimes and crimes committed by foreigners and social minority members. The repressions against foreigners may be partially caused by potential xenophobia, fear of new and different people, things, or customs. They may be partially caused by the perception of foreigners as easy "loot" because their defence is limited. They may also be partially caused by so-called "taking matters into one's own hands" in order to pay back for foreigners' delinquency and their potential expansion into the offender's territory. However, no reason may become acceptable justification of harming minority members or foreigners without any doubt. There are also no doubts about every case of crime committed by foreigners and minority members against a majority population. The reasons of foreigners' criminal behaviour are even more controversial than the previous issue. It may be one's need to emancipate oneself in a different environment or inadequate defence associated with the awareness of one's greater level of vulnerability. The potential cause rests in the different concept of moral and social norms or the feeling of greater anonymity when surrounded by a foreign nation and strangers. In any case, the critical role is played by the abuse of psychoactive substances and the forms of crime deriving from the offender's intelligence and profession (Čírtková, 2004).

\section{Social Conditions as the Delinquency Trigger}

Social conditions very strongly influence both delinquency and victimization. The critical role rests in upbringing, family relationships, relationships among peers, local crime rates associated with violence exposure, the role of violence presented by media, general attitude of the micro-environment and macro-environment to delinquency. The importance of social environment and its provided support becomes a more significant determinant in the case of criminal behaviour of national minorities and foreigners.
Social exclusion as the provoking factor makes delinquency and victimization more acute in the same way as the local problems factor and poverty. Social exclusion is often discussed as a problem in relation to discrimination against which the whole society fights.

The definition of discrimination set by the European Union applies generally. The rules of equal human treatment, regardless of nationality and ethnicity, are divided into two areas (Budilová \& Hirt, 2005): the first area includes direct discrimination. In this case, the treatment of some people seems to be less favourable for them than for other people in a similar situation due to race or ethnical reasons. The other area concerns indirect discrimination. In this case, seemingly neutral criteria or rules create a particular ethical or race origin that is disadvantaged in comparison with other people (without any legitimate, necessary, and objective reason and goal). The last sphere marked discrimination is discrimination resulting from race or ethnicity-based harassment, intimidation, bullying, and animosity. It reduces human dignity (Budilová \& Hirt, 2005).

\section{THE SITUATION IN THE CZECH REPUBLIC AS A PART OF THE CENTRAL-EAST EUROPEAN ZONE}

Delinquency of minority members and foreigners and their victimization may simultaneously feature numerous similarities and differences in the whole Europe. Such similarities and differences may be found in real situations, in the public presentation of such situations, in their handling and managing through politics, state, media, education and upbringing, through primary and secondary prevention, and mainly through the public represented by majority society. This work only focuses on some local problems, which cannot be applied to the whole population of the specified countries. In addition, all the available data concerning the issue of minority delinquency is highly limited due to its sensitivity in terms of personal data protection and the risk of labelling leading towards discrimination.

\section{Socially Excluded Localities}

As it has already been mentioned above, they are mostly local problems. For example, it is typical that more foreigners from a neighbouring country live near a state border. Then, it is not uncommon that a greater concentration of foreigners at one location is associated with more problematic inclusion into a majority society and greater crime rates -regarding the crime rates concerning foreigners and minority members; however, also delinquency affecting foreigners and minority members. That is the reason why the expression "socially excluded localities" is used. The state Police place more emphasis on socially excluded localities than on other localities mainly because a greater risk of conflicts. Of course, one cannot generalize, stating that one nationality is more problematic than other nationality within a whole country or even within a few countries together. It is necessary to perceive every problem separately at every locality and make no global conclusions. In addition, foreigners and national minority members occasionally move; therefore, socially excluded localities spontaneously get created and cease to exist at various locations. They keep changing and developing like the majority's position. 
A socially excluded locality means an area (building, street), which concentrates people featuring signs of social exclusion. These areas are symbolically negatively marked by citizens living nearby. The evaluated social exclusion is understood as gradually escalating exclusion from the full participation in social, material, and symbolic resources, which are produced, shared, and consumed by the majority of society in order to secure good living conditions, social life organization, and participation in decision-making (Steinert \& Pilgram, 2003).

According to The UK Poverty and Social Exclusion (PSE) Survey (Gordon et al., 2000), social exclusion occurs at localities characterized with the following symptoms: 1 . Lack of material resources; 2. Exclusion from the labour market; 3. Exclusion from the use of public or private services, including education; 4. Exclusion in social relationships.

Burchardt et al., (2002) talk about the four dimensions where the three of them match the PSE questionnaire: consumption, economic production, social relationships, and political participation in decision-making at the local and national level. Ethnicity often plays an important role in social exclusion in Central-Eastern Europe. More than a half of socially excluded localities are created by the Romanies (Anonymous sources of the Police of the Czech Republic, 2014) in Hungary (Dančák \& Fiala, 2000) and Slovakia, where numerous socially excluded localities are also created by Hungarian minorities (Dohányos, et al.2003). In Poland the socially excluded localities mostly comprise Germans and Ukrainians. However, there are no localities that would be as large and excluded as the Romanies' localities in the previously mentioned states (Matysiewicz et al., 2012). Unlike to Poland, Russians form the biggest and most problematic minority in Ukraine. Unfortunately, it is confirmed by the current alarming situation in Ukraine (available at: http://www.mzv.cz).

\section{Available Statistics}

The presented statistics are only associated with foreigners due to the act on the prevention of social minority discrimination. According to this act, minority members with citizenship in a particular country are considered citizens, regardless of their different nationality. Another complication in analysing the national minority delinquency and foreigners' delinquency rests in the fact that many of their members do not register as members of a given minority. In addition, many of them do not understand the question "What nationality do you feel being a member of?" Such a phenomenon is most common among the Romanies (Šišková, 1998).

Table 1 shows the individuals prosecuted in the Czech Republic during the first half of 2014. The offenders are divided into citizens and foreigners. When considering the percentage share of majority members and foreigners, it becomes clear that the foreigners' delinquency is sometimes even greater than of the majority society. In this statistics, the national minorities are included into the majority together with their delinquency. Then, the volume of crimes committed by the Czech citizens significantly drops, especially in specific areas. The foreigners' delinquency evolves rather negatively with time together with the growing number of foreigners - see Table 3 (Anonymous

Table 1. Some crimes of the Czech citizens and foreigners living on the territory of the Czech Republic (Anonymous sources of the Police of the Czech Republic, 2014).

\begin{tabular}{|c|c|c|c|c|}
\hline & \multicolumn{2}{|c|}{ Czech Citizens } & \multicolumn{2}{|c|}{ Foreigners } \\
\hline Robbery & 678 & 69 & 74 & 3 \\
\hline Intentional bodily harm & 1942 & 173 & 135 & 5 \\
\hline Blackmailing & 367 & 37 & 35 & 2 \\
\hline Breaking and entering & 607 & 75 & 32 & 3 \\
\hline The same household person abuse & 189 & 10 & 7 & 0 \\
\hline Sexual assault & 165 & 2 & 22 & 0 \\
\hline Pure theft & 8654 & 1645 & 423 & 81 \\
\hline Rioting & 1389 & 113 & 97 & 5 \\
\hline Illegal production and distribution of psychoactive substances & 1112 & 244 & 159 & 14 \\
\hline Obstruction of justice & 4568 & 400 & 391 & 39 \\
\hline
\end{tabular}


sources of the Police of the Czech Republic, 2014). Compared to the mildly growing delinquency of foreigners, the national minorities' delinquency seems to be relatively stable and without any significant changes. A specific position is held by the Romany minority, which comprises not only of Czech citizens, but also of individuals with the Polish, Slovak, Romanian, Bulgarian, and other citizenships (Ludka, 2012).

Table 2 indicates the situation of crime victims in the Czech Republic, compared to delinquency occurring in this area. There is the same problem like in the case of criminal offenders -it is only possible to identify victims among foreigners. The actual cope of victimization among national minority members remains hidden not only in the Czech Republic.

A study of public opinion of the minorities' delinquency in the Czech Republic mostly brings the following associations:

"The Romanies commit robberies, thefts, make a lot of debts, and abuse the social welfare system. The Vietnamese minority becomes rich through its illegal practices in drug trading and distribution. The Ukrainians specialize in organized crime and work illegally without employment contracts." (Ludka, 2012).

Unfortunately, such statements cannot be verified due to the lack of formal and objective information. It is interesting that foreigners with a Slovak citizenship are often not associated with any labelling when it comes to delinquency. Simultaneously, the Slovaks form the biggest minority in the Czech Republic and the biggest group of foreigners on the territory of this state. Of course, it relates to their top position in the ranking of foreigners' delinquency (see Table 3).

The delinquency of minorities in the rest of the discussed countries may differ significantly. It is also possible to find numerous similarities, for example, between the Czech
Republic and Slovakia. Probably due to the historical and territorial proximity, the biggest minority and also the biggest group of foreigners is formed by the Slovaks in the Czech Republic. The Czechs simultaneously become the biggest group representing a different nationality in Slovakia. That is the cause of the fact that the biggest number of crimes is associated with the Czechs in Slovakia and with the Slovaks in the Czech Republic. The crime rate is generally rising in Slovakia. The available statistics claim that in 2011, a total of 1,111 foreigners were prosecuted in Slovakia. In 2012, the number of prosecuted foreigners rose to 1,235 . Approximately one quarter of these prosecuted foreigners are Czechs (exactly 326 prosecuted in 2012). In terms of committed crimes, the second biggest group includes the Hungarians, Ukrainians, and Romanians. The number of foreigners legally sentenced in 2011 was 362 and 571 in the year 2012 (available at: http://www.lidovky.cz).

The association with general delinquency should be obvious:

"The crime rate multiplied in the nineties. The registered crime rate doubled in Central-Eastern Europe from 1989 to 2002, and it even tripled in the Czech Republic. After the fall of the authoritarian regimes, the public protection eased off in the area. Human "good living" may be strongly affected by such negative changes. In any case, the comparison of crime rates does not indicate extremely bad conditions in these countries. The proportion of those Slavs who became crime victims during the past five years and those who do not feel safe going home after sunset is exceptionally small. It is one of the smallest in the whole Europe. It is interesting that the proportion of Hungarians, Pols, and Czechs who do not feel safe in their proximity is relatively low. It is 10 and $12 \%$, which is much lower than the rate in the United Kingdom or France where more than one third of citizens do not feel

Table 2. Types of victimization and foreigners in the Czech Republic (Anonymous sources of the Police of the Czech Republic, 2014).

\begin{tabular}{|c|c|c|c|c|c|c|c|c|c|c|}
\hline \multirow[b]{2}{*}{ Victim nationality } & \multicolumn{2}{|c|}{ Violent crimes } & \multicolumn{2}{|c|}{ Crimes against morality } & \multicolumn{2}{|c|}{ Crimes against property } & \multicolumn{2}{|c|}{ Economic crimes } & \multicolumn{2}{|c|}{ Total } \\
\hline & 2012 & 2013 & 2012 & 2013 & 2012 & 2013 & 2012 & 2013 & 2012 & 2013 \\
\hline Total foreigners & 167 & 152 & 17 & 18 & 509 & 468 & 33 & 36 & 726 & 674 \\
\hline Vietnam & 24 & 14 & 1 & 1 & 61 & 69 & 9 & 9 & 95 & 93 \\
\hline Slovakia & 78 & 87 & 7 & 9 & 148 & 152 & 12 & 9 & 245 & 257 \\
\hline Germany & 12 & 9 & 2 & 0 & 109 & 86 & 5 & 6 & 128 & 101 \\
\hline Ukraine & 26 & 12 & 3 & 1 & 60 & 60 & 2 & 3 & 91 & 76 \\
\hline Poland & 7 & 5 & 1 & 0 & 19 & 8 & 2 & 2 & 29 & 15 \\
\hline Hungary & 0 & 0 & 0 & 0 & 0 & 1 & 0 & 0 & 0 & 1 \\
\hline Austria & 1 & 1 & 0 & 0 & 7 & 9 & 0 & 0 & 8 & 10 \\
\hline UK & 1 & 0 & 0 & 0 & 6 & 2 & 0 & 0 & 7 & 2 \\
\hline Other & 18 & 24 & 3 & 7 & 99 & 81 & 3 & 7 & 123 & 119 \\
\hline
\end{tabular}


Table 3. The number of crimes committed by foreigners in the Czech Republic (Anonymous sources of the Police of the Czech Republic, 2014).

\begin{tabular}{|c|c|c|c|c|c|}
\hline \multirow{2}{*}{$\frac{2012}{\text { Nationality }}$} & \multirow[b]{2}{*}{ Crimes } & \multirow{2}{*}{$\begin{array}{c}2013 \\
\text { Nationality }\end{array}$} & \multirow[b]{2}{*}{ Crimes } & \multicolumn{2}{|c|}{ The first half of 2014} \\
\hline & & & & Nationality & Crimes \\
\hline Slovakia & 341 & Slovakia & 350 & Slovakia & 127 \\
\hline Vietnam & 86 & Vietnam & 68 & Bulgaria & 22 \\
\hline Ukraine & 69 & Germany & 52 & Romania & 21 \\
\hline Germany & 56 & Ukraine & 49 & Ukraine & 18 \\
\hline Romania & 29 & Romania & 37 & Vietnam & 13 \\
\hline Poland & 22 & Poland & 24 & Germany & 9 \\
\hline Bulgaria & 19 & Bulgaria & 17 & Poland & 7 \\
\hline Moldavia & 6 & Latvia & 7 & Moldavia & 5 \\
\hline Russia & 4 & Moldavia & 7 & Kazakhstan & 4 \\
\hline Lithuania & 4 & Turkey & 7 & Slovenia & 3 \\
\hline Great Britain & 3 & Lithuania & 6 & Lithuania & 2 \\
\hline USA & 2 & Russia & 5 & France & 2 \\
\hline Yugoslavia & 2 & Belorussia & 3 & Croatia & 1 \\
\hline Holland & 2 & FYR of Macedonia & 3 & Italy & 1 \\
\hline Egypt & 2 & France & 3 & Kosovo & 1 \\
\hline France & 2 & Croatia & 2 & Hungary & 1 \\
\hline Croatia & 2 & Kosovo & 2 & Holland & 1 \\
\hline Italy & 2 & Cuba & 2 & Russia & 1 \\
\hline Japan & 1 & Switzerland & 2 & Uzbekistan & 1 \\
\hline Kosovo & 1 & Tunisia & 1 & Austria & 1 \\
\hline Cuba & 1 & Serbia & 1 & Switzerland & 1 \\
\hline China & 1 & Slovenia & 1 & Belorussia & 1 \\
\hline Albania & 1 & Yemen & 1 & & \\
\hline Belorussia & 1 & China & 1 & & \\
\hline Other & 1 & Uzbekistan & 1 & & \\
\hline Mongolia & 1 & Norway & 1 & & \\
\hline Austria & 1 & Palestine & 1 & & \\
\hline Bosnia/Herzegovina & 1 & Luxembourg & 1 & & \\
\hline Uzbekistan & 1 & Hungary & 1 & & \\
\hline Tunisia & 1 & & 0 & & \\
\hline Turkey & 1 & & 0 & & \\
\hline Serbia & 1 & & 0 & & \\
\hline Slovenia & 1 & & 0 & & \\
\hline
\end{tabular}

safe." (Lelkes, 2006)

\section{CONCLUSIONS}

The delinquency and victimization of national minorities and foreigners living within a particular nation is only a local problem associated with a greater concentration of other nationality members and a problem impacted by all the applicable physiological, psychological, social, economic, and political conditions.

The criminal law features numerous deficiencies; therefore, it may be abused in many ways - and it actually happens. The current delinquency often results from 
insufficient laws, and people do what they are allowed to do. On the other hand, the law deficiencies may not serve as justification for harming somebody else. From the victims' perspective, it is possible to meet numerous genuine victims and pseudo-victims, and with numerous obvious and hidden victims in whole populations. Clearly, victimization becomes more serious in the case of other nationality members, primarily due to the insufficiently supporting environment in the middle of a foreign nationality.

\section{CONFLICT OF INTEREST}

The author confirms that this article content has no conflict of interest.

\section{ACKNOWLEDGEMENTS}

None declared.

\section{REFERENCES}

Anderson, C.A. \& Bushman, B.J. (2002). Human aggression. Annual Reviews, 53, 27-51.

Bacchini, D., Affuso, G. \& Aquilar S. (2014). Multiple forms and settings of exposure to violence and values: unique and interactive relationships with antisocial behavior in adolescence. Journal of Interpersonal Violence, 1-24.

Bandura, A. (1977). Social learning theory. Englewood Cliffs, NJ: PrenticeHall.

Bard, M. (1986). The Crime Victim's Book. Secaucus, NJ: Citadel Press.

Baumaister, R.F. \& Bushman, B.J. (2004). Human nature and aggressive motivation. Revue international de psychologie sociale, 2, 205-220.

Budilová, L. \& Hirt, T. (2005). A Policeman in multicultural environment: Information manual for Police of Czech Republic. Prague: MVČR.

Burchardt, T., Le Grand, J., \& Piachaud, D. (2002). Understanding social exclusion: Introduction. Oxford: Oxford University Press.

Č́rtková, L. (2004). Forensic Psychology. Pilsen: Aleš Čeněk, s.r.o.

Dančák, B., Fiala, P. (2000). National policy in postcomunist lands. Brno: Mezinárodní politologický ústav.

Dohányos, R., Lelkes, G., \& Tóth, K. (2004). National minorities in Slovakia. Bratislava: Šamorín - Dunajská streda.

Dollard, J., Miller, N. E., Doob, L. W., Mowrer, O. H. \& Sears, R. (1939). Frustration and aggression, New Haven: Yale University Press.

Flowers, R. B. (1990). Minorities and criminality. New York: Greenwood Press.
Gordon, D., Levitas, R., Pantazis, Ch., Patsios, D., Payne, S., Townsend, P., Adelman, L., Ashworth, K., Middleton, S., Bradshaw, J., \& Williams, J. (2000). Poverty and social exclusion in Britain. York: Joseph Rowntree Foundation.

Kuchta, J., \& Válková, H. (2005). Basic criminology and penal policy. Prague: C.H. Beck.

Lelkes, O. (2006). Social exclusion in Central-Eastern Europe: Concept, measurement, and policy interventions. Geneva: Internationa Labour Office.

Lidovky. (2013). Foreigners criminality increases in Slovakia. Quarter of cases is caused by Czechs. Retrieved on: $20^{\text {st }}$ November 2014 from: http://www.lidovky.cz/na-slovensku-roste-kriminalita-cizincu-zactvrtinu-pripadu-mohou-cesi-131-/zpravy-

Ludka, T. (2012). Criminality of national minorities and ints prevention from the view of work of Czech Police. Brno: Univerzita Tomáše Bati ve Zlíně.

Marsh, I. Melville, G. \& Morgan, K. (2006). Theories of crime. New York: Taylor and Francis e-library.

Martínek, Z. (2009). Aggression and criminality of school youth. Praha: Grada Publishing.

Matoušková, I. (2013). Applied forensic psychology. Prague: Grada Publishing.

Matysiewicz, J., Laskowska, J., Niziol, M., \& Pawlik, W, (2012). Social exclusion of immigrants in Poland. Katowice: University of Economics in Katowice.

Ministerstvo zahraničních věcí (2010). Ukraine: Basic information about the territory. Retrievered on: $20^{\text {st }}$ November 2013 from: http://www.mzv.cz/jnp/cz/encyklopedie_statu/evropa/ukrajina/inde x.html.

Moulisová, M., \& Zoubková, I. (2004). Criminology and prevention of criminality. Prague: Armex Publishing s.r.o.

Munková, G. (2004). Social deviation. Prague: Karolinum.

National Center for Victims of Criminality (2008). The trauma of victimization: Overview. Retrieved on: $15^{\text {st }}$ July 2014 from: http://www.victimsofcrime.org/help-for-crime-victims/get-helpbulletins-for-crime-victims/trauma-of-victimization.

Ramírez, J.M., \& Andreu, J.M. (2006). Aggression, and some related psychological constructs (anger, hostility, and impulsivity). Some comments from a research project. Neuroscience and Biobehavioral Reviews, 30, 276-291

Šišková, T. (1998). Upbringing to tolerance and against rasism: Issues collection. Prague: Portál.

Sobotková, V., Osecká, T., Jelínek, M., Blatný, M., \& Hrdlička, M. (2012). Exposition of community violence and school bullying and their relation to antisocial behaviour in early adolescence. Československá psychologie, 56, 409-419.

Steinert, H., \& Pilgram, A. (2003). Welfare from Below: Struggles Against Social Exclusion in Europe. Aldershot: Ashgate Publishing Limited.

This is an open access article licensed under the terms of the Creative Commons Attribution Non-Commercial License (http://creativecommons.org/licenses/ by-nc/3.0/) which permits unrestricted, non-commercial use, distribution and reproduction in any medium, provided the work is properly cited. 